\title{
Use of chromium-enriched yeast in the manufacture of French bread
}

\author{
Utilização de levedura enriquecida em crómio no fabrico de pão tipo Francês
}

\author{
Carla Sá ${ }^{1,2}$, Ana Barata ${ }^{1}$, Carla Ramalho ${ }^{1}$, M. Cristiana Nunes ${ }^{1,3}$, Nelson Tavares* 1,2* \\ ${ }^{1}$ Universidade Lusófona de Humanidade e Tecnologias (ULHT), Lisboa, Portugal \\ ${ }^{2}$ CBIOS - Centro de Investigação em Biociências e Tecnologias da Saúde da Universidade Lusófona, Lisboa, Portugal \\ ${ }^{3}$ LEAF-Linking Landscape, Environment, Agriculture and Food, Instituto Superior de Agronomia, Universidade de Lisboa, \\ Lisboa, Portugal \\ *corresponding author: nelson.tavares@ulusofona.pt
}

\begin{abstract}
Bread enriched with chromium has been associated with improved glycemic control. The purpose of this study was the production of a bread with chromium (Cr III) -enriched yeast which maintained overall bread quality. A formulation of French bread was prepared using an inactive yeast enriched with $\mathrm{Cr}$ III for comparison against a control bread made with standard yeast. Yeast fermentation power and bread color and texture were evaluated. There were no differences in the color (crumb and crust) or the firmness of the bread crumb, despite a significant difference $(p<0.05)$ in the yellow tonality $\left(b^{*}\right)$ of the bread crumb. Regarding cohesiveness, samples present similar values but a significant difference $(p$ $<0.05$ ) was detected between control and chromium breads. The average value of chromium in bread after processing was $1.717 \mu \mathrm{g} / \mathrm{g}$ in dry samples. This study concludes that it is possible to produce French bread with chromium enriched - yeast without changing the technological process or dramatically affecting its color and texture characteristics.
\end{abstract}

Keywords: Yeast, chromium - enriched, French bread, texture, color

\begin{abstract}
Resumo
O pão enriquecido com levedura contendo crómio está associado à melhoria do controlo glicémico. Foi preparada uma formulação de pão tipo Francês usando uma levedura inativa enriquecida em Cr III e outra sem o metal, usada para efeitos de comparação e controlo. O presente trabalho tem como objetivo produzir um pão com levedura enriquecida em crómio trivalente (Cr III), mantendo a qualidade global do pão. Foi avaliado o poder de fermentação da levedura, a cor e a textura do pão. Em geral, as duas amostras de pão apresentam valores idênticos de cor (côdea e miolo) e firmeza (miolo), embora exista uma diferença significativa $(\mathrm{p}<0,05)$ na tonalidade amarela $\left(\mathrm{b}^{*}\right)$ do miolo. Em relação à coesividade, e embora os valores sejam similares, obteve-se uma diferença significativa $(\mathrm{p}<0,05)$ entre o pão controlo e o pão com crómio. $\mathrm{O}$ valor médio do crómio no pão após o processamento foi de $1,717 \mu \mathrm{g} / \mathrm{g}$ em amostra seca. Esta pesquisa conclui que é possível produzir pão tipo Francês com levedura enriquecida com Cr III sem alterar o processo tecnológico e sem afetar consideravelmente as suas características de cor e de textura.
\end{abstract}

Palavras-chave: Levedura enriquecida com crómio, pão tipo Francês, textura, cor 


\section{Introduction}

Bread is widely consumed as part of traditional diets and is an important source of dietary energy. Bread has been one of the bases of daily food, due to its nutritional characteristics and palatability, highly appreciated by consumers. The variety of cereal products and production techniques vary considerably around the world. The nutritional value of bread may increase depending on the mixture of other cereal flours or ingredients other than wheat flour (1).

Despite the variety of bread available on the market, consumers tend to prefer different types of bread in addition to the traditional white bread for some reasons, such as being healthy, having good taste, for the nutritional value and being recommended by some health professionals (1). In the current market context, and according to the European Food Safety Authority, the development of functional foods is a main priority to achieve beneficial nutritional properties and/or reduce risk factors for the development of a human disease (2). In this context, bread is an excellent vehicle for introducing functional ingredients. As a staple food, it contributes to the highest proportion of dietary carbohydrates and constitutes an inseparable part of the standard of the Mediterranean diet. In addition, consumption is a strategy to achieve better glycemic control, being beneficial to health $(3,4)$.

Trivalent chromium, or chromium 3 (Cr III), is found in foods and dietary supplements and is used to reduce the risk of diabetes or to complement conventional medical therapies used to control diabetes (5), although the World Health Organization recommends that chromium III supplementation should not exceed $250 \mu \mathrm{g} /$ day (6).

According to Racek et al. (7), bread with yeast enriched with $\mathrm{Cr}$ was beneficial in patients with type 2 diabetes mellitus, probably due to lower insulin resistance, leading to improved glucose tolerance. Yanni et al. (8) showed that bread enriched with $\mathrm{Cr}$ yeast (at a concentration of $500 \mu \mathrm{g} \mathrm{Cr} / 50 \mathrm{~g}$ of carbohydrates) is capable of reducing the postprandial glycemic response.

The objective of this work was to produce a bread with physical characteristics of color (crust and crumb) and crumb texture (firmness and cohesiveness) within the commercial standard of French bread, while taking advantage of the health benefits of including chromium in the diet of consumers.

\section{Introdução}

O pão é amplamente consumido como parte das dietas tradicionais sendo uma importante fonte de energia dietética. O pão tem sido uma das bases da alimentação diária, devido às suas características nutricionais e à sua palatibilidade, altamente apreciado pelo consumidor. A variedade de produtos de cereais e técnicas de produção variam consideravelmente em todo o mundo. $\mathrm{O}$ valor nutricional do pão pode aumentar consoante a mistura de outras farinhas de cereais ou de outros ingredientes para além da farinha de trigo (1).

Apesar da variedade de pães disponíveis no mercado, os consumidores tendem a preferir diferentes tipos de pão além do tradicional pão branco por alguns motivos, como ser saudável, ter bom gosto, pelo valor nutricional e ser recomendado por algum profissional de saúde (1). No contexto atual do mercado, e de acordo com a Autoridade Europeia de Segurança Alimentar (EFSA), o desenvolvimento de alimentos funcionais é uma prioridade, para alcançar propriedades nutricionais benéficas e/ou reduzir um fator de risco de desenvolvimento de determinada doença humana (2). Neste contexto, o pão é um excelente veículo para introdução de ingredientes funcionais, já que é um alimento de grande consumo, contribuindo com a maior proporção de hidratos de carbono na alimentação e constitui uma parte inseparável do padrão da dieta Mediterrânea. Além disso, o seu consumo é uma estratégia para alcançar melhor controlo glicémico, sendo benéfico à saúde $(3,4)$.

O crómio trivalente, ou crómio 3 (Cr III), encontra-se em alimentos e suplementos dietéticos e é usado para reduzir o risco de diabetes ou para complementar as terapias médicas convencionais usadas no controle do diabetes (5). A Organização Mundial da Saúde considera que a suplementação de crómio III não deve exceder $250 \mu \mathrm{g} / \mathrm{dia}$ (6).

De acordo com Racek et al (7), o pão com levedura enriquecida com $\mathrm{Cr}$ foi benéfico em pacientes com diabetes mellitus tipo 2 , provavelmente devido à menor resistência à insulina, levando à melhoria da tolerância à glucose. Yanni et al. (8) mostrou que o pão enriquecido com levedura de $\mathrm{Cr}$ (na concentração de $500 \mu \mathrm{g} \mathrm{Cr} / 50 \mathrm{~g}$ de hidratos de carbono) é capaz de reduzir a resposta glicêmica pós-prandial.

O objetivo do presente trabalho é obter um pão com características físicas de cor (côdea e miolo) e de textura do miolo (firmeza e coesividade) dentro do padrão comercial do pão tipo Francês, com os benefícios da inclusão do crómio na dieta dos consumidores. 


\section{Materials and methods}

\section{Yeast Production}

Saccharomyces cerevisiae enriched with $\mathrm{Cr}$ III, developed in a partner's laboratory, was grown in enriched medium. Lalmin ${ }^{\circledR} \mathrm{Cr} 2000$ (Lallemand, Estonia) is a dry and inactive whole cellulose yeast product containing high levels of chromium. The yeast cream is pasteurized, roller dried, and ground to provide 2.0 - $2.4 \mathrm{mg} \mathrm{Cr} / \mathrm{g}$.

Based on the fact that Lalmin ${ }^{\circledR} \mathrm{Cr} 2000$ contains $0.2 \%$ chromium (Source: https // bio-lallemand.com / healthingredients / products / lalminr-chromium /), $60 \mathrm{mg}$ of this product will provide $120 \mu \mathrm{g}$ of chromium, each bread produced ( $60 \mathrm{~g}$ of raw dough), according to the formulation in Table 1, will have approximately $0.2 \mathrm{mg}$ of chromium.

\section{Preparation of Bread}

The formulation of French bread is presented in Table 1. Initially, wheat flour T65 (Nacional), dry yeast (Instaferm), salt, Clean Label S500 improver (Puratos) and Lamin ${ }^{\circledR} \mathrm{Cr} 2000$ (only use in the sample with $\mathrm{Cr}$ ) were added to the kneader (Brettechnica, Portugal) and previously mixed ( $2 \mathrm{~min}$ ), at low speed. The water was then added, and the mixture kneaded at the fastest speed, until it was smooth and elastic (10 min). After resting for $15 \mathrm{~min}$, in the incubator (Ramalhos), at a temperature of $26^{\circ}-28^{\circ} \mathrm{C}$, the dough was divided into $60 \mathrm{~g}$ pieces,

\section{Material e Métodos}

\section{A Produção da Levedura}

A levedura Saccharomyces cerevisiae enriquecida com Cr III, desenvolvida no laboratório de um parceiro, foi cultivada em meio enriquecido. O Lalmin ${ }^{\circledR} \mathrm{Cr} 2000$ (Lallemand, Estónia) é um produto de levedura de celulose integral, seca e inativa, contendo níveis elevados de cromo. O creme de levedura é pasteurizado, seco com rolo e moído, fornecendo 2,0 - 2,4 mg Cr/g.

Tendo por base que o Lalmin ${ }^{\circledR}$ Cr2000 contém 0,2\% de crómio (Fonte: https//bio-lallemand.com/healthingredients/products/lalminr-chromium/), $60 \mathrm{mg}$ deste produto fornecerá $120 \mu \mathrm{g}$ de crómio, cada pão produzido (60 g de massa crua), conforme formulação da Tabela 1 , possuirá aproximadamente $0,2 \mathrm{mg}$ de crómio.

\section{Preparação do Pão}

A formulação do pão tipo Francês está apresentada na Tabela 1. Inicialmente, a farinha de trigo T65 (Nacional), a levedura seca (Instaferm), o sal, o melhorante Clean Label S500 (Puratos) e o Lamin ${ }^{\circledR}$ Cr2000 (utilizado apenas na preparação da amostra contendo crómio) foram adicionados na amassadeira (Brettechnica, Portugal) e previamente misturados (2 min), na velocidade baixa. A água foi então adicionada e a mistura amassada na velocidade mais rápida, até atingir o ponto de véu (10 min). Depois de descansar por 15 min na incubadora (Ramalhos), à temperatura

Table 1 - French bread formulation

Tabela 1 - Formulação de pão tipo Francês.

\begin{tabular}{|l|c|c|c|c|}
\hline & \multicolumn{2}{|c|}{ AControl } & \multicolumn{2}{c|}{ ACr } \\
\hline Ingredients / Ingredientes & $\%$ & g & $\%$ & g \\
\hline $\begin{array}{l}\text { Wheat flour T65 / } \\
\text { Farinha de Trigo T65 }\end{array}$ & 100 & 1000 & 100 & 1000 \\
\hline Lalmin Cr2000* & - & - & 0.3 & 3 \\
\hline Dry yeast / Levedura seca & 1 & 10 & 1 & 10 \\
\hline Water / Água & 60 & 600 & 60 & 600 \\
\hline Salt / Sal & 1.8 & 18 & 1.8 & 18 \\
\hline Clean label S500 / Melhorante S500 & 0.5 & 5 & 0.5 & 5 \\
\hline
\end{tabular}


moulded in the shape of French bread in the modeler (Brettechnica). After being placed on the baking sheets, the breads were left to rise for $60 \mathrm{~min}$ at $30^{\circ} \mathrm{C}$ in the incubator (Ramalhos, Portugal). Finally, with the help of a stylus, cuts were made in the breads and then they were baked in the oven (Ferneto, Portugal), preheated to $220^{\circ} \mathrm{C}$ (upper element) and $230^{\circ} \mathrm{C}$ (lower element), with low humidity level for $15 \mathrm{~min}$. In the production of control breads, the same procedure was repeated, with the exception of the addition of Lalmin ${ }^{\circledR}$ Cr2000.

\section{Sampling}

The bread samples were cut into $2 \mathrm{~cm}$ slices measured with a digital caliper (Platinum, United Kingdom). The ends of the bread were neglected, leaving only the central part. The analysis of texture and color were performed after cooling the breads on the day they were prepared.

\section{Yeast fermentation power}

To determine the fermentative power of the yeast for the control and $\mathrm{Cr}$ samples, $40 \mathrm{~g} \times 4$ of dough was removed from each of the samples, after kneading. That quantity was placed in beakers for measuring the volume, left to incubate at $30^{\circ} \mathrm{C}$, being removed and photographed at 30, 60, 90 and 120 min (4 beakers/ sample).

\section{Color}

The color was measured using a Minolta CR-300 colorimeter (Minolta, Japan), equipped with a standard D65 illuminator and a phase angle of $2^{\circ}$. The results were expressed using the CIELab* color system that uses Cartesian axes with three coordinates: L*, which quantifies luminosity and ranges from zero (black) to 100 (white); $a^{*}$, to indicate the intensity of red and $-\mathrm{a}^{*}$ to indicate the intensity of green; $b^{*}$ to indicate the intensity of yellow and $-b^{*}$ to indicate the intensity of blue. The values of the coordinates $a^{*}$ and $b^{*}$ typically range from -60 to 60 . Measurements were conducted under the same light conditions, using a white standard and fluorescent artificial light, at room temperature. Each sample was tested ten times for the crumb. Due to the lack of homogeneity in the color of the crust, the number of measurements for the crust was increased from 10 to 30 . de $26^{\circ}-28^{\circ} \mathrm{C}$, a massa foi dividida em pedaços de 60 g e moldada em formato de pão Francês na modeladora (Brettechnica). Depois de colocados nas assadeiras, os pães ficaram a fermentar por $60 \mathrm{~min}$ a $30^{\circ} \mathrm{C}$, na incubadora (Ramalhos, Portugal). Por fim, com auxílio de um estilete, foram feitos cortes nos pães e, em seguida, foram assados durante $15 \mathrm{~min}$ no forno (Ferneto, Portugal), com pouca humidade, pré aquecido a $220^{\circ} \mathrm{C}$ (teto) e $230^{\circ} \mathrm{C}$ (lastro). Na produção dos pães controlo, o mesmo procedimento foi repetido, com exceção da adição de $\operatorname{Lalmin}^{\circledR} \mathrm{Cr} 2000$.

\section{Amostragem}

As amostras de pão foram cortadas em fatias de $2 \mathrm{~cm}$ com o auxílio de um paquímetro digital (Platinum, Reino Unido). Foram desprezadas as pontas do pão, ficando apenas a parte central. As análises de textura e cor foram realizadas após o arrefecimento dos pães no dia da preparação.

\section{Poder de fermentação da levedura}

Para a determinação do poder fermentativo da levedura na amostra controlo e na amostra com $\mathrm{Cr}$, foram retiradas $40 \mathrm{~g} \times 4$ de massa crua de cada uma das amostras, após amassadura. Essa quantidade foi colocada em provetas para medição do volume, e deixada a incubar a $30^{\circ} \mathrm{C}$, sendo retirada e fotografada aos 30,60, 90 e $120 \mathrm{~min}$ (4 provetas/amostra).

\section{Cor}

A cor foi medida usando um colorímetro Minolta CR300 (Minolta, Japão), equipado com um iluminante padrão D65 e um ângulo de fase de $2^{\circ}$. Os resultados foram expressos usando o sistema de cores CIELab* que utiliza eixos cartesianos com três coordenadas: L*, que quantifica a luminosidade e varia de zero (preto) até 100 (branco); a*, para indicar a intensidade de vermelho e -a* para indicar a intensidade de verde; $b^{*}$ para indicar a intensidade de amarelo e $-b^{*}$ para indicar a intensidade de azul. Os valores das coordenadas a* e $\mathrm{b}^{*}$, normalmente, variam de -60 até 60 . As medições foram conduzidas sob as mesmas condições de luz, usando um padrão branco e luz artificial fluorescente, à temperatura ambiente. Cada amostra foi testada dez vezes para o miolo. Devido à falta de homogeneidade da cor da côdea, o número de medições na côdea foi aumentado de 10 para 30. 
The total color difference between the bread containing $\mathrm{Cr}$ and the AControl was calculated using the equation:

$$
\Delta \mathrm{E}^{*}=\left[\left(\Delta \mathrm{L}^{*}\right) 2+\left(\Delta \mathrm{a}^{*}\right) 2+\left(\Delta \mathrm{b}^{*}\right) 2\right] 1 / 2 \quad[\mathbf{E q} \cdot \mathbf{1}] .
$$

\section{Texture}

The bread samples were cut into $2 \mathrm{~cm}$ slices with the aid of a digital caliper (Platinum). The texture was evaluated on a TA-XTplus texturometer (Stable MicroSystems, United Kingdom) equipped with a $5 \mathrm{~kg}$ load cell using Texture Profile Analysis (TPA). A cylindrical probe 19 $\mathrm{mm}$ in diameter (P19), a cross-head speed of $1 \mathrm{~mm} / \mathrm{s}$ and a waiting time of $5 \mathrm{~s}$ between the two penetration cycles were used. The measurements were repeated ten times for each bread sample. Firmness and cohesiveness were the texture parameters used to discriminate different bread samples, as has been previously used by other authors $(9,10)$. Firmness is the maximum resistance to penetration $(\mathrm{N})$ and cohesiveness is related to the level of structure between the elements that take part in the bread structure (11).

\section{Chromium III analysis}

The measurement of Cr III was carried out using a validated methodology and used by Soares et al. (12) in bread samples after drying.

\section{Statistical analysis}

Data were presented by means (standard deviation), the Shapiro-wilk test was used to test the normality of the distribution of variables. The variables with normal distribution were tested using the student's $t$ test. The $\mathrm{b}^{*}$ color of the crust did not present a normal distribution and was tested by the equivalent non-parametric test, the Mann-Whitney test. The data were analyzed using SPSS version 23.0 (IBM Inc., Armonk, NY, USA), Results were considered statistically significant when $p$-value $<0.05$.
A diferença total de cor entre o pão com $\mathrm{Cr}$ e a amostra AControl foi calculada usando a seguinte equação

$$
\Delta \mathrm{E}^{*}=\left[\left(\Delta \mathrm{L}^{*}\right) 2+\left(\Delta \mathrm{a}^{*}\right) 2+\left(\Delta \mathrm{b}^{*}\right) 2\right] 1 / 2 \quad \text { [Eq. 1]. }
$$

\section{Textura}

As amostras de pão foram cortadas em fatias de $2 \mathrm{~cm}$ com o auxílio de um paquímetro digital (Platinum). A textura foi avaliada num texturómetro TA-XTplus (Stable MicroSystems, Reino Unido) equipado com uma célula de carga de $5 \mathrm{~kg}$ usando a Análise de Perfil de Textura (TPA). Utilizou-se uma sonda cilíndrica de $19 \mathrm{~mm}$ de diâmetro (P19), uma velocidade de $1 \mathrm{~mm} / \mathrm{s}$ e um tempo de espera de $5 \mathrm{~s}$ entre os dois ciclos de penetração. As medições foram repetidas dez vezes para cada amostra de pão. Os parâmetros de textura utilizados para discriminar as amostras foram a firmeza e coesividade, tal como reportado noutros estudos realizados em pão $(9,10)$. A firmeza corresponde à resistência máxima à penetração da sonda $(\mathrm{N})$ e a coesividade está relacionada com o nível de estruturação entre os elementos responsáveis pela estrutura do pão (11).

\section{Doseamento do Crómio III}

O doseamento do Cr III foi realizado com metodologia validada e usada por Soares et al. (12) em amostras de pão após secagem.

\section{Análise estatística}

Os dados foram apresentados por média (desvio padrão), o teste de Shapiro-wilk foi utilizado para testar a normalidade da distribuição das variáveis. As variáveis com distribuição normal foram testadas usando o $t$ teste de student. A variável $\mathrm{b}^{*}$ da cor da crosta, não apresentou distribuição normal e foi testada pelo teste não paramétrico equivalente, o teste de Mann-Whitney. Os dados foram analisados pelo SPSS versão 23.0 (IBM Inc., Armonk, NY, EUA), sendo considerado um resultado com significado estatístico, quando $p$-value $<0,05$. 
Table 2 - Volume of the dough, in $\mathrm{mL}$, after $30,60,90$ and $120 \mathrm{~min}$ of fermentation in the incubator at $30^{\circ} \mathrm{C}$, for the control sample (AControl) and the sample with chromium (ACr).

Tabela 2 - Volume da massa, em mL, após 30, 60, 90 e 120 min de fermentação, em incubadora a $30^{\circ} \mathrm{C}$, para a amostra controlo (AControl) e a amostra com crómio (ACr).

\begin{tabular}{|c|c|c|c|c|}
\hline $\begin{array}{l}\text { Fermentation time / } \\
\text { Tempo fermentação (min) }\end{array}$ & 30 & 60 & 90 & 120 \\
\hline AControl (mL) & 40 & 90 & 120 & 160 \\
\hline $\mathrm{ACr}(\mathrm{mL})$ & 40 & 90 & 124 & 176 \\
\hline
\end{tabular}
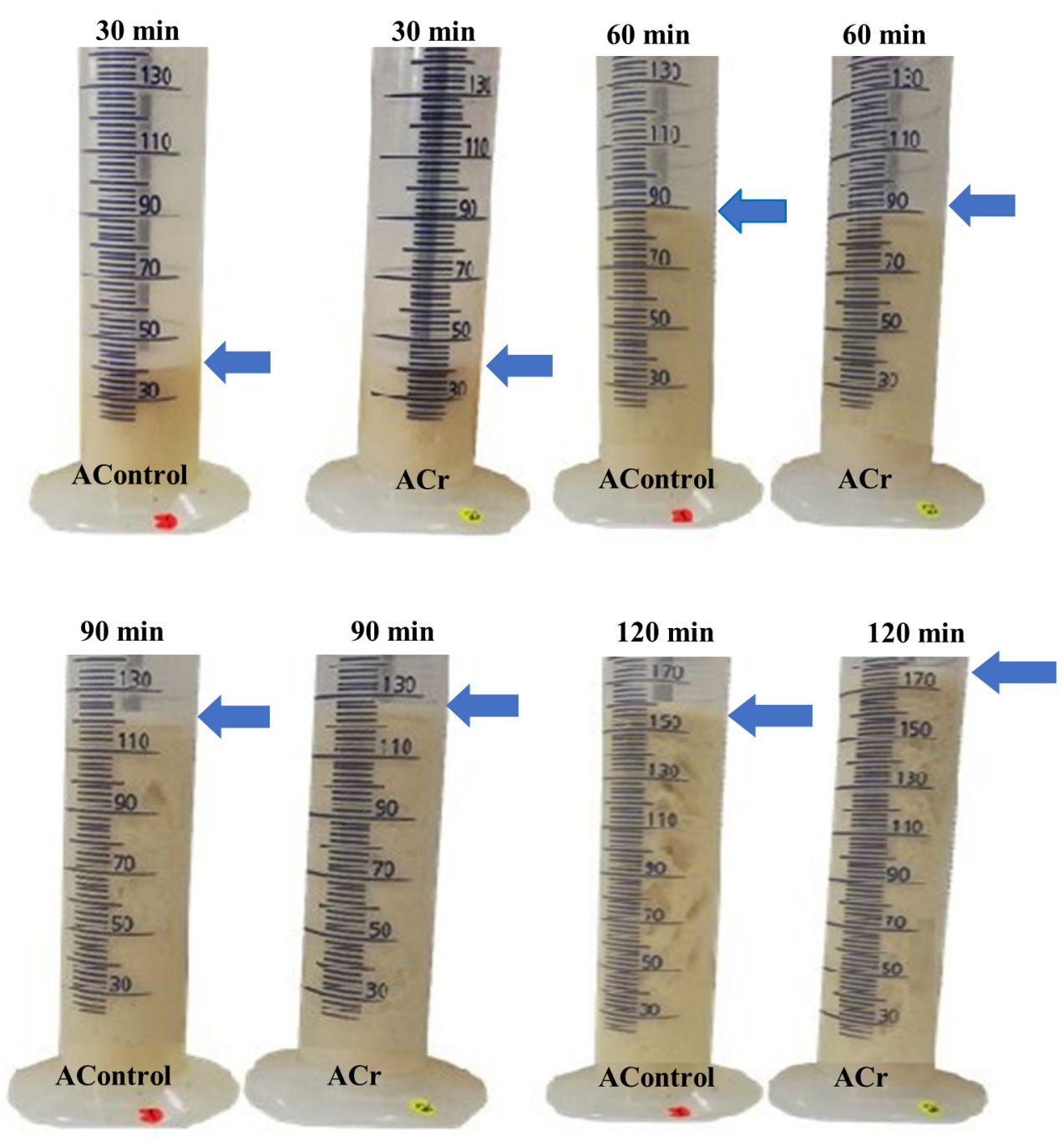

Figure 1 - Photographic register of dough growth at $30 \mathrm{~min}, 60 \mathrm{~min}, 90 \mathrm{~min}$ and $120 \mathrm{~min}$, after leavening at $30^{\circ}$ $\mathrm{C}$ in the incubator.

Figura 1 - Registo fotográfico do crescimento da massa aos $30 \mathrm{~min}, 60 \mathrm{~min}, 90 \mathrm{~min}$ e $120 \mathrm{~min}$, após levedar a $30^{\circ} \mathrm{C}$ na incubadora. 


\section{Results and Discussion}

The dough volume test that evaluates the fermentation power of yeast allows to determine if Cr III influences the fermentative capacity (13). The results obtained are showed in Figure 1 and in Table 2. It is possible to observe that in shorter fermentations (up to $60 \mathrm{~min}$ ) the volume of the dough does not differ between the AControl and $\mathrm{ACr}$ samples. And in longer fermentations (90 and $120 \mathrm{~min}$ ) the ACr sample has greater volume than the AControl. This is in agreement with the results obtained by Jialong et al. (14), where the growth of S. cerevisiae in the presence of chromium showed a lag phase much longer than in the absence of chromium. In terms of technological performance, this effect of chromium on yeast activity may be more interesting in long-fermentation breads, which are increasingly produced and consumed.

The results obtained for the crumb color, crust color and crumb texture parameters are presented in Tables 3 and 4.

\section{Resultados e Discussão}

O teste de volume de massa que avalia o poder de fermentação da levedura permite determinar se o Cr III influencia a capacidade fermentativa (13). Os resultados obtidos estão apresentados na Figura 1 e na Tabela 2. É possível observar que em fermentações mais curtas (até $60 \mathrm{~min}$ ) o volume da massa não difere entre as amostras AControl e ACr. Em fermentações mais longas (90 e $120 \mathrm{~min}$ ) a amostra $\mathrm{ACr}$ apresenta maior volume que a amostra AControl. Este resultado está de acordo com o estudo de Jialong et al. (14), where the growth of S. cerevisiae in the presence of chromium showed a lag phase much longer than in the absence of chromium. Em termos tecnológicos, este efeito do crómio na atividade da levedura poderá ser mais interessante em pães de fermentação longa, que são cada vez mais procurados e produzidos.

Os resultados obtidos para os parâmetros de cor do miolo e côdea dos pães e para os parâmetros de textura do miolo são apresentados nas Tabelas 3 e 4.

Table 3 - Results for the bread color (crumb and crust) for the control sample (AControl) and the sample with chromium (ACr) ( \pm standard deviation)

Tabela 3 - Resultados das análise de cor no pão (miolo e côdea) com crómio (ACr) e sem crómio (AControl) que serviu de controlo ( \pm desvio-padrão).

\begin{tabular}{|c|c|c|c|c|c|c|c|c|}
\hline & \multicolumn{3}{|c|}{ Crumb color / cor do miolo } & \multirow[b]{2}{*}{$\Delta \mathrm{E}^{*}$} & \multicolumn{4}{|c|}{ Crust color / cor da côdea } \\
\hline & $L^{*}$ & $a^{*}$ & $b^{*}$ & & $L^{*}$ & $a^{*}$ & $b^{*}$ & $\Delta \mathrm{E}^{*}$ \\
\hline AControl & $\begin{array}{c}79.73 \\
( \pm 2.20)\end{array}$ & $\begin{array}{c}-0.20 \\
( \pm 0.07)\end{array}$ & $\begin{array}{c}13.12^{*} \\
( \pm 0.79)\end{array}$ & - & $\begin{array}{c}72.19 \\
( \pm 2.28)\end{array}$ & $\begin{array}{c}7.91 \\
( \pm 1.62)\end{array}$ & $\begin{array}{c}34.66 \\
( \pm 1.50)\end{array}$ & - \\
\hline $\mathrm{ACr}$ & $\begin{array}{r}80.09 \\
( \pm 1.41)\end{array}$ & $\begin{array}{c}-0.22 \\
( \pm 0.18)\end{array}$ & $\begin{array}{c}14.36^{*} \\
( \pm 0.55)\end{array}$ & 1.29 & $\begin{array}{r}72.59 \\
( \pm 2.79)\end{array}$ & $\begin{array}{c}7.27 \\
( \pm 2.54)\end{array}$ & $\begin{array}{r}34.02 \\
( \pm 2.74)\end{array}$ & 0.99 \\
\hline
\end{tabular}

*A significant difference $(p$ value $<0.05)$ was found between the samples for all color parameters.

*Foi encontrada uma diferença significativa (para um valor de $p<0,05$ ) entre as amostras para todos os parâmetros de cor

Table 4 - Results for the bread color (crumb and crust) for the control sample (AControl) and the sample with chromium (ACr) ( \pm standard deviation)

Tabela 4 - Resultados das análise de cor no pão (miolo e côdea) com crómio (ACr) e sem crómio (AControl) que serviu de controlo ( \pm desvio-padrão).

Texture / Textura

\begin{tabular}{ccc}
\hline & Firmness / firmeza & Cohesiveness / coesividade \\
\cline { 2 - 3 } AControl & $0.591( \pm 0.091)$ & (Adimensional / sem dimensão) \\
\hline ACr & $0.680( \pm 0.100)$ & $0.826^{*}( \pm 0.016)$ \\
\hline
\end{tabular}

*A significant difference $(p$ value $<0.05)$ was found between the samples

*Uma diferença significativa (para um valor de $p<0,05$ ) foi encontrada entre amostras. 
Both samples have a high $\mathrm{L}^{*}$ parameter, a* negative (green) and $b^{*}$ positive (yellow), for the crumb. A significant difference $(p<0.05)$ was found between the AControl and the ACr sample for the $b^{*}$ parameter. $L^{*}$ and $a^{*}$ values do not present significant differences $(p>$ 0.05 ). The color of the crumb is more directly related to the coloration of the ingredients, since it does undergo less reactions during baking, in contrast to the crust that undergoes Maillard reactions, changing it drastically (15). Thus, the sample produced with $\mathrm{Cr}$ has a slightly more yellow color, probably due to the coloring of Lalmin ${ }^{\circledR}$ Cr2000. Bread crust samples present high L*, $\mathrm{a}^{*}$ positive (red) and $\mathrm{b}^{*}$ positive (yellow), and they do not present significant differences $(\mathrm{p}<0.05)$ between $\mathrm{ACr}$ and the AControl, suggesting that the addition of Lalmin $^{\circledR}$ Cr2000 does not affect the color, nor will it affect the consumer's choice. In addition, the literature indicates that the $\mathrm{L}^{*}$ brightness values of the crust around 70 are well accepted by consumers (15), which is in line with the results obtained $(\sim 72)$. For coordinates $\mathrm{a}^{*}$ and $\mathrm{b}^{*}$, no patterns were found in the literature. The total color difference $\Delta \mathrm{E}^{*}$ between Acontrol and $\mathrm{ACr}$ is 1.29 in crumb and 0.99 in bread crust. Despite higher difference was obtained for crumb, several authors consider that the human eye only can differentiate colors when the total color difference $\Delta \mathrm{E}^{*}>5$ [16].

Regarding texture, values obtained by the Texture Profile Analysis (TPA) may have been affected by the characteristic of the samples that had approximate size and shape, but not standardized. For firmness values there are no significant difference $(p<0.05)$ between samples, and AControl cohesiveness is significantly higher $(\mathrm{p}<0.05)$ compared to ACr, despite the similarity values.

These results suggest that French bread enriched in chromium can be produced and consumed like traditional French bread, since they have very similar color and texture, both for crust and crumb.

From the nutritional point of view, according to the studies published by Yanni et al. (4), Costello et al. (5), and Raceck et al. (6), French bread made with yeast with the addition of chromium would have a differential related to its supply of chromium and its contribution in improving metabolism, thus the two food EFSA health claims approved for chromium III could be used (17). The average value of chromium in bread after processing was $1.717 \mu \mathrm{g} / \mathrm{g}$ in dry samples. Yanni et al. (8) showed that the daily consumption of a yeast enriched with $\mathrm{Cr}$ with the same proportion of carbohydrates was able to assist in the treatment/control of diabetes by improving glucose tolerance and insulin resistance, with a
Ambas as amostras apresentam o parâmetro $\mathrm{L}^{*}$ elevado, parâmetros cromáticos $\mathrm{a}^{*}$ negativo (verde) e $b^{*}$ positivo (amarelo), para o miolo. Verificam-se diferenças significativas $(\mathrm{p}<0,05)$ para a coordenada $\mathrm{b}^{*}$, que em média é maior na amostra $\mathrm{ACr}$ em relação ao AControl. A luminosidade $L^{*}$ e a coordenada a* não diferem significativamente $(p>0,05)$ entre amostras. A cor do miolo está mais diretamente relacionada com as coloração dos ingredientes, uma vez que sofre menos alterações durante a cozedura, em contraste com a côdea que sofre reações de Maillard, alterando-a consideravelmente (15). Desta forma, a amostra produzida com $\mathrm{Cr}$ apresenta uma cor ligeiramente mais amarela, provavelmente devido à coloração de Lalmin ${ }^{\circledR}$ Cr2000. A côdea apresenta elevada luminosidade (L*), coordenada $\mathrm{a}^{*}$ positivo (vermelho) e coordenada $\mathrm{b}^{*}$ positivo (amarelo). Nenhum dos parâmetros de cor apresenta diferenças significativas $(\mathrm{p}<0,05)$ entre amostras, sugerindo que a adição de Lalmin ${ }^{\circledR} \mathrm{Cr} 2000$ não afeta a cor da côdea, nem afetará a escolha do consumidor. Além disso, a literatura indica que os valores de luminosidade $\mathrm{L}^{*}$ da crosta em torno de 70 são bem aceites pelos consumidores (15), o que está de acordo com os resultados obtidos $(\sim 72)$. Para as coordenadas $\mathrm{a}^{*} \mathrm{e} \mathrm{b}^{*}$, não foram encontrados padrões na literatura. A diferença total de cor $\Delta \mathrm{E}^{*}$ entre Acontrol e ACr é 1,29 no miolo e 0,99 na côdea do pão. Apesar de se confirmer uma maior diferença de cor no miolo, vários autores consideram que o olho humano só consegue discriminar as cores quando a diferença $\Delta \mathrm{E}^{*}$ $>5[16]$.

Em relação à textura, os valores obtidos recorrendo à Análise do Perfil de Textura (Texture Profile Analysis - TPA) podem ter sido afetados pela característica das amostras que tinham tamanho e forma aproximados, mas não padronizados. Verifica-se que embora os valores de firmeza sejam maiores na amostra $\mathrm{ACr}$, não foi encontrada diferença significativa $(p<0,05)$ entre este pão e o controlo (AControl), enquanto que a coesividade do pão AControl é significativamente superior ao pão $\mathrm{ACr}(\mathrm{p}<0,05)$, apesar dos valores serem semelhantes.

Os resultados obtidos sugerem que o pão de trigo tipo Francês enriquecido em crómio pode ser produzido e consumido como o pão Francês tradicional, uma vez que possuem propriedades semelhantes de cor e textura, quer ao nível da côdea quer do miolo.

Do ponto de vista nutricional, conforme os estudos publicados por Yanni et al. (4), Costello et al. (5) e Racek et al. (7), o pão Francês elaborado com uma levedura com adição de crómio terá um diferencial em 
significant reduction in glycated hemoglobin (HbA1c), weight loss, and lower systolic blood pressure. Thus, this product may represent an excellent alternative to fiber bread, a current option to control postmeal plasma glucose, which has characteristics different than white bread and thus reduces the interest of some consumers $(18,19)$.

\section{Conclusions}

Although some studies have been published regarding the impact on human health of using yeast enriched with $\mathrm{Cr}(4,5,7,8)$, to the best of our knowledge, there are no studies regarding the impact of yeast enriched in chromium on the overall bread quality (texture and color). The results of our work demonstrate that it is possible to produce a bread using yeast enriched with Cr III without dramatic changes to its texture and color parameters. Based on these results, the development of this product for future marketing is of interest.

Nevertheless, our study had some limitations, including the use of French bread for the assessment of physical properties. Further, the breads produced were cut, resulting in a lack of homogeneity in the color of the crust. The number of measurements was increased to minimize this variability. Furthermore, despite the generally existing correlation between sensory results and the instrumental results obtained in the Texture Profile Analysis and with the colorimeter, it will be important to apply hedonic testing to these breads using a consumer panel, especially regarding flavour. Evaluations of the effects on glycemic index and the postprandial response are also suggested. relação ao seu aporte de crómio, contribuindo para a melhoria do metabolismo, podendo ser utilizadas as duas alegações de saúde aprovadas pela EFSA para o crómio trivalente (17). O valor médio obtido para o crómio do pão em estudo após o processamento foi de $1,717 \mu \mathrm{g} / \mathrm{g}$ em amostra seca. Yanni et al. (8) mostraram que o consumo diário de um fermento enriquecido com $\mathrm{Cr}$ na mesma proporção de hidratos de carbono foi capaz de auxiliar no tratamento/controlo da diabetes, pela melhoria da tolerância à glucose, resistência à insulina, redução significativa na hemoglobina glicada (HbA1c), perda de peso e menor pressão arterial sistólica. Desta forma, este produto pode representar uma excelente alternativa ao pão de fibra, que até agora tem sido a opção no controlo da glicemia pós-prandial, mas que tem propriedades estruturais distintas do pão branco, tornando-o menos interessante para alguns consumidores $(18,19)$.

\section{Conclusões}

Há alguns estudos publicados sobre o impacto da adição de levedura enriquecida com crómio na saúde humana $(4,5,7,8)$, mas não conhecemos nenhum estudo sobre o efeito da utilização de levedura enriquecida em crómio nas características de qualidade (textura e cor) de pão. Os resultados deste trabalho experimental demonstram que é possível produzir um pão com levedura enriquecida com $\mathrm{Cr}$ III sem alterar consideravelmente as propriedades de textura e cor do pão. Com base neste estudo, será de interesse desenvolver este produto para comercialização futura.

No entanto, este estudo teve algumas limitações, como o uso de pão Francês para a avaliação de propriedades físicas; os pães produzidos foram cortados, resultando em falta de homogeneidade na cor da crosta. Para minimizar essa instabilidade, o número de medições foi aumentado. Por outro lado, apesar da correlação geralmente existente entre os resultados sensoriais e os resultados instrumentais obtidos na Análise de Perfil de Textura e com o colorímetro, será importante submeter estes pães a um teste hedónico recorrendo a um painel de consumidor, especialmente devido ao atributo sabor. Sugere-se também a avaliação do índice glicémico e da resposta pós-prandial. 


\section{Authors Contributions Statement}

NT - conceptualization and study design; $\mathrm{AB}$ and $\mathrm{CR}$ - experimental implementation; $\mathrm{CN}$ - analysis; $\mathrm{AB}$, $\mathrm{CR}$, and CS - drafting, editing, reviewing, figures and graphics; NT- supervision and final writing.

\section{Conflict of Interests}

The authors declare there are no financial or personal relationships that could present a potential conflict of interests.

\section{Declaração sobre as contribuições do autor}

NT - desenho do estudo; AB e CR - implementação experimental; CN - Análises; AB, CR e CS - elaboração, edição, revisão, figuras e gráficos; NT - supervisão e redação final.

\section{Conflito de Interesses}

Os autores declaram não haver relações financeiras ou pessoais que possam representar potencial conflito de interesses. 


\section{References / Referências}

1. Demirtas B., Kaya A., Dagistan E. (2018). Consumers' Bread Consumption Habits and Waste Status: Hatay/Turkey Example. Turkish Journal of Agriculture - Food Science and Technology, 6 (11), 1653-1661.

2. Regulation (EC) No 1924/2006 of the European Parliament and of the Council of 20 December 2006 on nutrition and health claims made on foods.

3. Sajdakowska M., Gebski J., Zakowska-Biemans S. (2019). Willingness to eat bread with health benefits: habits, taste and health in bread choice. Public Health, 167, 78-87.

4. Yanni A.E., Stamataki N., Stoupaki M. (2017). Cr-enriched yeast: beyond fibers for the management of postprandial glycemic response to bread. European Journal of Nutrition, 56 (4), 1445-53.

5. Costello R.B., Dwyer J.T., Bailey R.L. (2016). Chromium supplements for glycemic control in type 2 diabetes: limited evidence of effectiveness. Nutrition Reviews, 74 (7), 455-68.

6. World Health Organization (1996). Trace elements in human nutrition, (A Report of a re- evaluation of the role of trace elements in human health and nutrition). Geneva.

7. Racek J., Sindberg C.D., Moesgaard S. (2013). Effect of chromium-enriched yeast on fasting plasma glucose, glycated haemoglobin and serum lipid levels in patients with type 2 diabetes mellitus treated with insulin. Biological Trace Element Research, 155 (1), 1-4.

8. Yanni A.E., Stamataki N.S., Konstantopoulos P. (2018). Controlling type-2 diabetes by inclusion of Cr-enriched yeast bread in the daily dietary pattern: a randomized clinical trial. European Journal of Nutrition, 57 (1), 259-67.

9. Nunes M.C., Graça C., Vlaisavljevic S., Tenreiro A., Sousa I., Raymundo A. (2020). Microalgae cell disruption: Effect on the bioactivity and rheology of wheat bread. Algal Research, 45, 101749.

10. Nunes M.C., Fernandes I., Vasco I., Sousa I., Raymundo A. (2020). Tetraselmis chuii as a sustainable and healthy ingredient to produce gluten-free bread: Impact on structure, colour and bioactivity. Foods, 9, 579.

11. Bourne M. (2002). Food Texture and Viscosity, 2nd ed.; Academic Press: London, UK.

12. Soares, M.E., Vieira E., Bastos M.L. (2009). Chromium Speciation Analysis in Bread Samples. Journal of Agricultural and Food Chemistry, 58 (2), 1366-1370.

13. De Vuyst L., Van Kerrebroeck S., Leroy F. (2017). Microbial Ecology and Process Technology of Sourdough Fermentation. Advances in Applied Microbiology, 100, 49-160.

14. Jianlong W., Zeyu M., Xuan Z. (2004). Response of Saccharomyces cerevisiae to chromium stress. Process Biochemistry, 39 (19), 12311235 .

15. Johann V. (2018). O padrão de qualidade do pão francês na visão dos consumidores do Rio Grande do Sul. Retrieved February 20, 2021, from: https://www.lume.ufrgs.br/bitstream/handle/10183/174913/00106181859.pdf?sequence=1

16. Francis F.J., Clydesdale F.M. (1975). Food Colorimetry: Theory and Applications; The AVI Publishing Company Inc.: Westport, CT, USA.

17. Commission Regulation (EU) No 432/2012 of 16 May 2012, establishing a list of permitted health claims made on foods, other than those referring to the reduction of disease risk and to children's development and health.

18. Laukova M., Kohajdova Z., Karovicova J. (2017). Effects of cellulose fiber with different fiber length on rheological properties of wheat dough and quality of baked rolls. Food Science and Technology International, 23 (6), 490-9.

19. Blandino M., Sovrani V., Marinaccio F. (2013). Nutritional and technological quality of bread enriched with an intermediated pearled wheat fraction. Food Chemistry, 141 (3), 2549-57. 